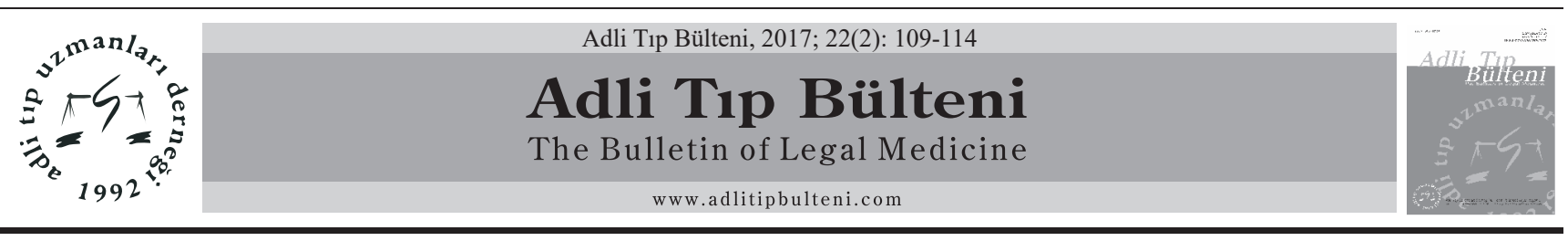

ARAŞTIRMA / RESEARCH ARTICLE

doi: $10.17986 / \mathrm{blm} .2017228069$

\title{
Attachment, Emotion Recognition and Impulsivity: As A Risk of Child Sexual Abuse
}

\section{Bağlanma, Duygu Tanıma ve Dürtüsellik: Çocuk Cinsel İstismarına İlişkin Riskler}

Esra Demirci ${ }^{1}$, Didem Behice Öztop ${ }^{2}$, Sevgi Özmen1, Çağlar Özdemir ${ }^{3}$

${ }^{I}$ Department of Child and Adolescent Psychiatry, Erciyes University School of Medicine, Kayseri

${ }^{2}$ Department of Psychology, Gelişim University, Istanbul

${ }^{3}$ Department of Forensic Medicine, Erciyes University School of Medicine, Kayseri

\begin{abstract}
Objective: It has been reported that certain children are more at risk of sexual abuse: these risks factors are defined as individual, familial, social and institutional factors. However, data from clinical risks in the literature is limited. In this study, we aimed to determine the clinical risk factors of sexual abuse.

Materials and Methods: 22 female and 12 male, sexually abused children and 34 healthy volunteer children were involved in this study. Patients and volunteers were assessed with the Parental Bonding Instrument (PBI), Reading Mind from Eyes Test (RMET) and the UPPS impulsive behavior scale.

Results: There were no significant differences in maternal attachment scores in either group but the paternal attachment scores were statistically significantly lower in the study group. The RMET scores were statistically significantly lower in the study group than in the control group. The UPPS impulsive behavior scale non-persistence subscores were statistically significantly higher in the study group than in the control group.

Conclusion: Sexual abuse is known as the most difficult type of trauma to treat and preventing the risk of identification is of the utmost importance. Further studies with larger sample are needed to determine the clinical risk factors of sexual abuse.
\end{abstract}

Keywords: Child; Sexual Abuse; Attachment; Emotion Recognition; Impulsivity.

\section{Özet}

Amaç: Bazı çocukların cinsel istismar riski daha fazla olduğu bildirilmiş olup: bu risk faktörleri bireysel, ailevi, sosyal ve kurumsal faktörler olarak tanımlanmaktadır. Buna rağmen literatürdeki klinik riskler ile ilgili bu veriler kısıtlıdır. Bu nedenle, çalışmamızda cinsel istismarın klinik risk faktörlerini belirlemeyi amaçladık.

Gereç ve Yöntem: Bu çalışmaya 22 kız, 12 erkek olmak üzere cinsel istismara uğrayan 34 çocuk ve 34 sağlıklı gönüllü dahil edildi. Çalışmaya alınan her iki grup Ebeveyne Bağlama Ölçeği (EBÖ), Gözlerden Zihin Okuma Testi ve UPPS dürtüsel davranış ölçeği ile değerlendirildi.

Bulgular: Her iki grupta anne bağlanma skorlarında istatistiksel olarak anlamlı farklılık saptanmazken, baba bağlanma puanları istatistiksel olarak anlamlı derecede düşük bulundu. Gözlerden Zihin Okuma Testi puanları çalışma grubunda kontrol grubuna göre istatistiksel olarak anlamlı derecede düşüktü. UPPS dürtüsel davranış ölçeği sebatsızlık alt ölçeği puanları çalışma grubunda kontrol grubuna göre istatistiksel olarak anlamlı derecede yüksekti.

Sonuç: Cinsel istismar, tedavi edilmesi gereken en zor travma tipi olarak bilinmekte olup; risk faktörlerinin belirlenmesi istismarın önlenmesinde büyük önem taşımaktadır. Cinsel istismarın klinik risk faktörlerini belirlemek için daha geniş örneklemli çalışmalara ihtiyaç vardır.

Anahtar Kelimeler: Çocuk; Cinsel İstismar; Bağlanma; Duygu Tanıma; Dürtüsellik.

\section{Introduction}

Child abuse is a repeatable trauma which is difficult to identify and treat, and has influences extending later life of a child (1). Abuse is a public health issue that cannot only affect child and his/her parents but also social organizations, jurisprudence, educational system and fields of industry (2). In the literature, the prevalence of sexual abuse has been reported as $10-40 \%$ in children (3). Its

Corresponding Author: Assist. Prof. Dr. Esra Demirci

Erciyes University School of Medicine, Department of Child and

Adolescent Psychiatry, Kayseri

E-mail: esra_z_d_r@hotmail.com

Arrived: 02.02.2017 Revized: 07.06.2017 Accepted: 13.06.2017 prevalence is estimated to be $11.8 \%$ worldwide (4). Frequency of exposure to sexual abuse is higher by 1.5 to 5.5 folds in girls when compared to boys $(5,6)$.

In previous studies, it was reported that certain children are at higher risk for exposure to sexual abuse (7). These risks include individual and familial factors and social and institutional factors $(8,9)$. In the literature, there are limited data about risks in terms of psychiatric disorders or clinical symptoms. Moreover, it has been reported that behavioral disorders, tic disorders and stuttering can be risk factor for abuse $(10,11,12)$. However, in general, psychopathologies that develop following abuse have been emphasized in studies $(2,13,14)$. 
To best of our knowledge, there is no study assessing insecure attachment, emotion recognition deficits and impulsivity as risks factors for sexual abuse in the literature. However, insecure attachment is seen more commonly in child abuse and neglect (15). Also, it was known that parent-child attachment affects child's social relationships, particularly his/her relations with peers, and development of social and emotional abilities in the child (16,17). A large number of studies have indicated that attachment is related to several facets of emotion $(18,19)$. There is evidence from adults showing that attachment security is associated with patterns of attending toward or away from threat related stimuli such as angry faces (20). On the other hand, it was reported that adolescents with secure attachment patterns have best adaptation capability and exhibit minimum risktaking/impulsive behavior (21) and it was known that impulsivity affects emotion recognition (22). Healthy people normally evoke the automatic arousal response to salient emotional change, but individuals with higher impulsivity have impairments in emotional change detection, likely because of the weakened fronto-occipital feedback functional connection. On the contrary to healthy populations, certain populations with abnormal impulsivity may respond more selectively to emotional saliency that is potentially related to abnormal behaviors and enhance sensory-perceptual change detection (22). Besides, it was known that the rate of abuse is higher in psychopathologies that goes on with insecure attachment, emotion recognition deficits and impulsivity, such as attention deficit hyperactivity disorder (ADHD), eating disorders, bipolar affective disorder (23-26), than that of healthy people.

In the light of these data, firstly, we suggest that children those have insecure attachment, emotion recognition deficits and higher impulsivity are at higher risk for exposure to sexual abuse. We suggested that there is a relationship between attachment, emotion recognition and impulsivity. We aim to take more attention to identify clinical risk factors as well as sociodemographic risk factors for sexual abuse as being an important public issue, which will guide the community, particularly the clinicians, regarding to the prevention of abuse and taking measures is also required.

This study included 33 individuals exposed to sexual abuse who were assessed as forensic cases between 2013 and 2014. All cases were assessed regarding attachment, emotion recognition and impulsivity, attempting to identify clinical risk factors for sexual abuse.

\section{Materials and Methods}

\subsection{Participants}

The study included 22 girls and 12 boys aged between 12 to 18 years who were graduated from primary school at least, without mental retardation. Patients who were assessed in Child and Adolescent Psychiatry Department between 2013 and 2014; who were not diagnosed with a psychiatric disease before abuse or with a psychiatric disease other than acute stress disorder during follow-up period after the abuse; and completed the treatment and 6-months of follow-up afterwards were included in the study.

The patients who had diagnosis of psychiatric disease before abuse or those developed any psychiatric disease other than acute stress disorder after abuse were excluded in order to assess impulsivity and emotion recognition independently from psychiatric disorder. In the cases, data regarding psychological status before abuse was based on information gathered from patient and his/her parents, as it is impossible to perform a psychological assessment before an abuse.

Control group consisted of age- and sex-matched healthy volunteers without any known psychiatric, neurological and metabolic disorder. In both groups, children of single parents were excluded.

The parents of all children and adolescents gave informed consent before participation. Schedule for Affective Disorders and Schizophrenia for School-Age Children-Present and Lifetime Version (K-SADS-PL) was applied to all cases and controls. Patients and volunteers who participated in the study were assessed with the UPPS impulsive behavior scale, Reading Mind from Eyes Test (RMET) and Parental Bonding Instrument (PBI).

This study was approved by the Ethics Committee of Erciyes University Medical School (2014/430) and it has been conducted in accordance with the Code of Ethics of the World Medical Association (Declaration of Helsinki). The objectives and procedure of the study were explained to the participants and their parents and their written informed consents were taken.

\subsection{Scales and Tests Used in the Study} Schedule for Affective Disorders and Schizophrenia for School Age Children-Present and Lifetime Version - K-SADS-PL): This scale was developed by Kaufman et al. (1997) after publication of DSM-IV in 1994. K-SADS-PL allows screening more than 20 different psychiatric disorders (27). Reliability and validity studies of the Turkish version of the scale were conducted by Gökler et al. (28).

Parental Bonding Instrument (PBI): The PBI consists of 25 statements, of which 12 refer to the "care" and 13 to the control ("protection") that subjects recall receiv- 
ing from the mother or father during their first 16 years of life. The items are scored on a 4-point Likert scale that indicates the subject's agreement with the item statement. The validity and reliability of the Turkish version was made by Kapçı and Küçüker (29).

Reading Mind from Eyes Test (RMET): The RMET has been developed as a subtle measure of emotion recognition. This test is made up of photos of actors' eyes and requires the participant to identify the emotion that the actor is portraying (30). Reliability and validity studies of the Turkish version of the scale were conducted by Yildırım et al. (31).

Table 1. Sociodemographic characteristics of CSA victims and control groups and their parents

\begin{tabular}{|l|c|c|}
\hline & $\begin{array}{c}\text { CSA group } \\
(\mathbf{n = 3 4 )}\end{array}$ & $\begin{array}{c}\text { Control group } \\
(\mathbf{n}=\mathbf{3 4})\end{array}$ \\
\hline Gender (F/M) & $22 / 12$ & $22 / 12$ \\
\hline Mean age (years) & $14.35 \pm 3.32$ & $14.35 \pm 3.32$ \\
\hline $\begin{array}{l}\text { Years of education } \\
\text { (min-max) }\end{array}$ & $5-9$ & $5-9$ \\
\hline $\begin{array}{l}\text { Parents: Living } \\
\text { together }\end{array}$ & 29 & 31 \\
\hline Divorced & 5 & 3 \\
\hline $\begin{array}{l}\text { Parental } \\
\text { psychopathology }\end{array}$ & $2(\mathrm{Depression}$ & 0 \\
\hline Father's mean age & $43.10 \pm 5.35$ & $42.06 \pm 5.04$ \\
\hline Mother's mean age & $39.33 \pm 6.45$ & $38.25 \pm 6.75$ \\
\hline $\begin{array}{l}\text { Father's years of } \\
\text { education (mean) }\end{array}$ & $11 \pm 3.74$ & $11 \pm 3.86$ \\
\hline $\begin{array}{l}\text { Mother's years of } \\
\text { education (mean) }\end{array}$ & $7 \pm 5.67$ & $7 \pm 6.01$ \\
\hline $\begin{array}{l}\text { Income level of the } \\
\text { family: }\end{array}$ & 9 & 3 \\
\hline Low & 41 & 23 \\
\hline Normal & & \\
\hline High & & \\
\hline
\end{tabular}

The UPPS Impulsive Behavior Scale: The UPPS impulsivity scale is a 46 -item inventory created to measure four distinct personality pathways to impulsive behaviour. The inventory was derived through a factor-analytic method that included well known impulsivity scales. Whiteside and Lynam presented information on the internal consistency, as well as divergent and external validity of the UPPS. Each item is rated on a $0=$ not at all to $4=$ very much - point scale. Individuals high on impulsivity are characterized by low urgency and perseverance scores and high urgency and sensation Seeking scores. The validity and reliability of the Turkish version was made by Yargıç et al. (32).

\subsection{Statistical Analysis}

Data were analyzed by using SPSS version 21.0. Chisquare test was used to compare numeric data. Student's $\mathrm{t}$ test was used to compare continuous data while Mann Whitney U test was used if data were skewed. Pearson's correlation test was used to assess relationships among variables. " $\mathrm{p}<0.05$ " was considered to be significant in all analysis.

\section{Results}

The study included 34 children (22 girls and 12 boys) aged between 12 to 18 years who exposed to sexual abuse and 34 age- and sex-matched healthy volunteers (Table 1).

When groups were compared regarding total PBI scores, it was found that there was no significant difference in scores of maternal attachments while paternal attachment scores were significantly lower in children exposed to abuse $(p=0,029)$ (Table 2$)$. When total RMET scores were considered, a significant difference was detected between groups $(\mathrm{p}<0,001)$ (Table 2 ).

When impulsivity scores were considered, it was found that scores in perseverance subscale of UPSS impulsive behavior scale was significantly higher in the case group than controls $(p<0,001)$, while no significant differences were detected in the scores of urgency and sensation seeking subscales between groups (Table 3).

Table 2. RMET and PBI Scales Total Scores in sexual abuse and control groups

\begin{tabular}{|l|l|l|l|}
\hline $\begin{array}{l}\text { RMET and PBI Scales } \\
\text { Total Scores }\end{array}$ & \multicolumn{1}{|c|}{$\begin{array}{c}\text { Sexual Abuse Group } \\
(\mathrm{n}=34) \\
\text { mean } \pm 1 \text { SD }\end{array}$} & \multicolumn{1}{c|}{$\begin{array}{c}\text { Control Group } \\
(\mathrm{n}=34) \\
\text { mean } \pm 1 \text { SD }\end{array}$} & \\
\hline RMET & $21,4 \pm 2,6$ & $28,4 \pm 2,1$ & $\mathrm{t}=0,842, \mathrm{df}=2, \mathbf{p}<\mathbf{0 , 0 0 1}$ \\
\hline PBI-Mother & $51,1 \pm 8,80$ & $52,75 \pm 5,46$ & $\mathrm{t}=0,587, \mathrm{df}=31, \mathrm{p}=0,561$ \\
\hline PBI- Father & $43,52 \pm 9,45$ & $50.50 \pm 6,15$ & $\mathrm{t}=-2,286, \mathrm{df}=31, \mathbf{p}=\mathbf{0 , 0 2 9}$ \\
\hline
\end{tabular}


Table 3. Scores of UPPS impulsive behavior scale in sexual abuse and control groups

\begin{tabular}{|l|c|c|c|}
\hline UPPS Impulsive Behavior Scale & $\begin{array}{c}\text { Sexual Abuse Group } \\
(\mathrm{n}=34) \\
\text { mean } \pm 1 \mathrm{SD}\end{array}$ & $\begin{array}{c}\text { Control Group } \\
\mathrm{N}(\mathrm{n}=34) \\
\text { mean } \pm 1 \mathrm{SD}\end{array}$ & \\
\hline Perseverance (lack of) & $34,47 \pm 5.58$ & $21,38 \pm 5,29$ & $\mathrm{t}=11,65, \mathrm{df}=20, \mathrm{p}<0,001$ \\
\hline Urgency & $31.33 \pm 6.35$ & $29.15 \pm 5.54$ & $\mathrm{t}=1.575, \mathrm{df}=20, \mathrm{p}=0,131$ \\
\hline Premeditation (lack of) & $25,91 \pm 6,54$ & $23,44 \pm 4,24$ & $\mathrm{t}=0,872, \mathrm{df}=20, \mathrm{p}=0,451$ \\
\hline Sensation Seeking & $34,74 \pm 6,86$ & $34,23 \pm 6,60$ & $\mathrm{t}=-0,348, \mathrm{df}=20, \mathrm{p}=0,732$ \\
\hline
\end{tabular}

$* \mathrm{p}<0,05$

In both case and control groups, no significant correlations were detected between impulsivity and RMET scores. There were no significant correlations between maternal attachment scores and RMET scores in either group while there was a positive correlation between paternal attachment scores and RMET scores in the study group $(\mathrm{r}=.673, \mathrm{p}=0.033)$.

\section{Discussion}

In the interactive model of child abuse, risk factors are classified as potentiating and compensating factors (33). Compensating factors include good temperament, high intelligence, elasticity, high adaptive ability, physical attractiveness, social and interpersonal skills, capabilities, successful coping skills, problem solving skills and history of having good parents $(33,34)$. There is limited data about clinical risks for psychiatric disorder in the literature; and previous studies evaluated psychopathologies developed after abuse in general $(2,13)$.

Insecure attachment is observed more commonly in all groups who were exposed to child abuse and neglect than those did not (15). In a study investigating attachment in children aged between 7 and 13 years, it was observed that children with sexual abuse exhibited conflictual, ambivalent attachment pattern to their mothers (35). In our study, no significant different was detected in scores of maternal attachments between groups. This may be related with the limited sample size in our study. As an important result, paternal attachment scores were found to be lower in the case group. In a longitudinal study by Grossman et al., it was found that attachment to mother had greater effect during early childhood while the effect of attachment to father was more prominent at mid-childhood (36). So, this result of our study can be interpreted as attachment to father can be a risk factor for sexual abuse given the mean age of children exposed to abuse which could be considered to be middle age group in this study. Also, we found that the RMET scores were significantly lower in sexual abuse group. There is no study assessing emotion recognition deficits a risk factor for sexual abuse. On the other hand; findings suggest the importance of emotion dysregulation in predicting risk perception among victims and of improving victims' emotion regulation skills in revictimization risk reduction interventions (37). Emotion recognition is conceptually more primary than emotion regulation because regulation is only possible after recognition has occurred (38).

As an important result, we found a positive correlation between paternal attachment scores and RMET scores in the study group. Although, there is no study assessing emotion recognition deficits and relationship with attachment; it could be thought that such children may have difficulties to understand intention of individuals when considering effects of attachment on the development of social and emotional abilities, specially on emotion recognition. On the other hand, it was reported that father-child attachment security has positive effects on children's social and emotional development (39) and attachment to father was more prominent at mid-childhood (36). Children who are securely attached to their fathers display behavior that reflects a sense of trust, comfort, and emotional availability (40). Also, insecure individuals may be more attracted to accept insecure partners and avoidant adolescents were involved with partners who had less healthy personality profiles (41). In this point, paternal attachment could be a compensating factor for sexual abuse in two ways; 1- Affects the emotion recognition abilities in positive direction, specially in mid-childhood. 2-Considering the most of abusers were male and boyfriend in our study ( $F / M=32 / 2$, boyfriend 16$)$, secure attachment to father prevent the searching for the wrong attachment figure that result in abuse.

In previous studies, urgency assessed in UPSS impulsive behavior scale was linked to borderline personality disorder and bulimia nervosa, while lack of premeditation to antisocial personality disorder, perseverance to ADHD; and sensation seeking to substance abuse disorders $(32,42)$. Although Experiences of abuse is higher 
in borderline personality disorder and bulimia nervosa $(25,42)$ and the presence of ADHD which is frequently accompanied by impulsivity is reported as a predisposing factor to abuse (23), there is no study considering impulsivity alone as a risk factor for abuse. In our study, scores in urgency subscale of UPSS impulsive behavior scale were found to be significantly higher in the cases with abuse from both sexes. In cases with abuse, the increase in urgency score is striking given lack of any psychiatric disorders such as ADHD. This suggests that impulsivity which is found to be higher in cases with abuse could be considered as risk factor for abuse. In our study, no significant correlation was detected between impulsivity and RMET scores. This may be due to the limited sample size in our study.

Although our study included victims of abuse who developed no psychiatric disorder other than acute stress disorder and completed treatment and follow-up periods, results raising the questions that "Could high impulsivity and impairment in facial emotion recognitions found in our study be risk for abuse in cases with sexual abuse?" or "Can attachment to father be considered as a risk factor for abuse given the low paternal attachment scores?" At this point, there is a need for further studies with larger sample size that can identify clinical risk factors for child and adolescent abuse which is an important public issue.

\section{Limitations}

Limited sample size is one of the limitation of our study. In the cases, data regarding psychological status before abuse was based on information gathered from patient and his/her parents.

\section{Funding and disclosure}

All authors declare no biomedical financial interests or potential conflicts of interest.

\section{References}

1. Behrman, RE, Kliegman RM, Arvin AM. Abuse and Neglect of Children. In: Johnson CF (ed). Nelson Textbook of Pediatrics. 16. press. Philadelphia: WB Saunders pres; 2000. p.1469-1471.

2. Akduman GG, Ruban C, Akduman B, Korkmaz I. Child and sexual abuse. Adli Psikiyatri Dergisi; 2006;3(1):9-14.

3. Renteria SC. Sexual abuse of female children and adolescents-detection, examination and primary-care. Ther Umsch 2005; 62: 230-237. doi: 10.1024/0040-5930.62.4.230

4. Stoltenborgh M, Van Ijzendoorn MH, Euser EM, Bakermans-Kranenburg MJ. A global perspective on child sexual abuse: Meta-analysis of prevalence around the world. Child Maltreat 2011; 16:79-101. doi: 10.1177/1077559511403920

5. Pereda N, Guilera G, Forns M, Gomez-Benito J. The international epidemiology of child sexual abuse: a continuation of Finkelhor. Child Abuse Negl 2009; 33: 331-342. doi. org/10.1016/j.chiabu.2008.07.007
6. Sedlak A, Mettenburg J, Basena M, Petta I, McPherson K, Green A, Li S. Fourth national incidence study of child abuse and neglect (NIS-4): Report to Congress. Washington D.C: US Department of Health and Human Services, Administration for Children and Families, 2010.

7. Porter R. Child Sexual Abuse within the Family. London: Great Britain: Tavistock Publication Ltd; 1984.

8. Hay T, Jones L. Societal interventions to prevent child abuse and neglect. Child Welfare 1994; 73 (3): 379-403

9. Wolfe DA, Repucci ND, Hart S. Child abuse prevention: knowledge and priorities. J Clin Psychol 1995; 24: 5. doi: 10.1080/0047228X.1995.10801976

10. Bethea L. Primary prevention of child abuse. Am Fam Physician 1999;59(6):1577-1591.

11. Sahiner UM, Yurdakok K, Kavak US, Cetin I. Medical aspects of child abuse. Katk1 Pediatri Dergisi 2001; 22(5): 276-285.

12. Simsek F, Ulukol B, Bingöler B. Çocuk İstismarına Disiplin Penceresinden Bakış. Turkish Adli Bilimler Dergisi 2004; $3(1): 47-52$

13. Yates A. Sexual abuse of children. In: Wiener JM (ed). Textbook of child adolescent psychiatry. 2nd ed. Washington; American Psychiatric Press;1997. p. 699-709

14. Walrath C, Ybarra M, Holden EW. Children with reported histories of sexuel abuse: multiple perspectives to understand clinical and psychosocial profiles. Child Abuse Negl 2003; 27:509-524. doi: 10.1016/S0145-2134(03)00035-8

15. Troisi A, Massaroni P, Cuzzolaro M. Early separation anxiety and adult attachment style in women with eating disorders. Br J Clin Psychol 2005; 44(1): 89-97 doi: 10.1348/014466504X20053

16. Laible D. Attachment with parents and peers in late adolescence: Links with emotional competence and social behavior. Pers Individ Dif 2007; 43:1185-1197. doi: 10.1016/j. paid.2007.03.010

17. Booth-LaForce C, Rubin KH, Rose-Krasnor L, Burgess KB. Attachment and friendship predictors of psychosocial functioning in middle childhood and the mediating roles of social support and self-worth.. In: Kerns KA, Richardson RA (eds). Attachment in middle childhood. New York: Guilford Press; 2005 p.161-188

18. Chris Fraley R, Niedenthal PM, Marks M, Brumbaugh C, Vicary A. Adult attachment and the perception of emotional expressions: probing the hyperactivating strategies underlying anxious attachment. J Pers 2006;74:1163-1190. doi: 10.1111/j.1467-6494.2006.00406.x

19. Donges US, Kugel H, Stuhrmann A, Grotegerd D, Redlich $\mathrm{R}$, Lichev V, et al. Adult attachment anxiety is associated with enhanced automatic neural response to positive facial expression. Neuroscience 2012; 220:149-157. doi: 10.1016/j.neuroscience.2012.06.036.

20. Dewitte M, De Houwer J. Adult attachment and attention to positive and negative emotional face expressions. J Res Pers 2008; 42: 498-505. doi: 10.1016/j.jrp.2007.07.010

21. Görgün S, Tiryaki A, Topbas M. Üniversite öğrencilerinde madde kullanma ve anne babaya bağlanma biçimleri. Anadolu Psikiyatri Dergisi 2010; 11:305-312.

22. Soshi T, Noda T, Ando K, Nakazawa K, Tsumura H, Okada T. Neurophysiological modulation of rapid emotional face processing is associated with impulsivity traits. BMC Neurosci 2015;9:16:87. doi: 10.1186/s12868-015-0223-x 
23. Briscoe-Smith AM, Hinshaw SP. Linkages between child abuse and attention deficit/hyperactivity disorder in girls: Behavioral and social correlates. Child Abuse Negl 2006; 30:1239-1255. doi: 10.1016/j.chiabu.2006.04.008

24. Cancro R. Problems related to abuse and neglect. In: Sadock BJ, Sadock VA (eds). Kaplan \& Sadock's Concise Textbook of Clinical Psychiatry, 9.press. Baltimore: Lippincott Williams \&Wilkins pres; 2004. p.370-376

25. Waxman SE. A Systematic Review of Impulsivity in Eating Disorders. Eur Eat Disord Rev 2009; 17(6):408-25. doi: 10.1002/erv.952

26. Russo M, Mahon K, Shanahan M, Solon C, Ramjas E, Turpin $\mathrm{J}$, et al. The association between childhood trauma and facial emotion recognition in adults with bipolar disorder. Psychiatry Res 2015; 229(3):771-776. doi: 10.1016/j.psychres.2015.08.004.

27. Kaufman J, Birmaher B, Brent D, Rao U, Flynn C, Moreci $\mathrm{P}$, Williamson $\mathrm{D}$, Ryan $\mathrm{N}$. Schedule for affective disorders and schizophrenia for school-age children present and life time version: initial reliability and validity data. J Am Acad Child Adolesc Psycihatry 1997; 980-988. doi: 10.1097/00004583-199707000-00021

28. Gökler B, Ünal F, Pehlivantürk B, Kültür EÇ, Akdemir D, Taner Y. Okul Çağı Çocukları İçin Duygulanım Bozuklukları ve Şizofreni Görüşme Çizelgesi-Şimdi ve Yaşam Boyu Şekli-Türkçe Uyarlamasının Geçerlik ve Güvenirliği. Turk J Child Adolesc Ment Health 2004;11(3):109-116.

29. Kapc1 GE, Kücüker S. The Parental Bonding Instrument: Evaluation of Psychometric Properties with Turkish University Students. Turkish Journal of Psychiatry 2006; 17:286-295.

30. Baron-Cohen S, Wheelwright S, Hill J, Raste Y, Plumb I. The "Reading the mind in the eyes" test revised version: a study with normal adults, and adults with Asperger syndrome or high-functioning autism. J Child Psychol Psychiatry 2001;42:241-251. doi: 10.1017/S0021963001006643

31. Yildirim EA, Kasar M, Guduk M, Ates E, Kucukparlak I, Ozal MO Gözlerden Zihin Okuma Testi'nin Türkçe Güvenirlik Çalışması. Türk Psikiyatri Dergisi 2011; 22(3): 177-186.

32. Yargıç I, Ersoy E, Oflaz SB. UPPS Measuring impulsivity of psychiatric patients using UPPS impulsive behavior scale. Bulletin of Clinical Psychopharmacology 2011; 21(2):139-14. doi: 10.5455/bcp.20110706024203
33. Cicchetti D, Rizley R. Developmental perspectives on the etiology intergenerational transmission, and sequelae of child maltreatment. New Dir Child Adolesc Dev 1981;11:31-56. doi: 10.1002/cd.23219811104

34. Breiding JM, Reza A, Gulaid J, Blanton C, Mercy JA, Dahlberg LL, Dlamini N, Bamrah S. Risk factors associated with sexual violence towards girls in Swaziland. Bull World Health Organ 2011; 89:203-210 doi: 10.2471/ BLT.10.079608

35. Trickett PK, Noll JG, Reiffman A, Putnam FW. Variants of intrafamilial sexual abuse experience: Implications for short- and long-term development. Dev Psychopathol 2001; 13:1001-1019.

36. Grossmann K, Grossmann KE, Fremmer-Bombik E, Kindler $\mathrm{H}$, Scheurer-Englisch H, Zimmerman P. The uniqueness of the child-father attachment relationship: Fathers' sensitive and challenging play as a pivotal variable in a 16-year longitudinal study. Social Development 2002;11:307-331 doi: 10.1111/1467-9507.00202

37. Walsh K, DiLillo D, Messman-Moore TL. Lifetime sexual victimization and poor risk perception: Does emotion dysregulation account for the links? $\mathrm{J}$ interpers violence 2012:27(15);3054-3071. doi: $10.1177 / 0886260512441081$

38. Yoo SH, Matsumoto D, LeRoux JA. The influence of emotion recognition and emotion regulation on intercultural adjustment. Int J Intercult Relat 2006; 30(3), 345-363. doi: 10.1016/j.ijintrel.2005.08.006

39. Lamb ME, Pleck JH, Charnov EL, Levine JA. Paternal behavior in humans. American Zoologist 1985;25:883-894.

40. Brown GL, Mangelsdorf SC, Neff, C. Father involvement, paternal sensitivity, and father- child attachment security in the first 3 years. J Fam Psychol 2012;26(3):421. doi: $10.1037 / \mathrm{a} 0027836$

41. Collins NL, Cooper ML, Albino A, Allard L. Psychosocial vulnerability from adolescence to adulthood: A prospective study of attachment style differences in relationship functioning and partner choice. J pers 2002;70(6): 965-1008. doi: 10.1111/1467-6494.05029

42. Whiteside SP, Lynam, DR. The Five Factor Model and impulsivity: using a structural model of personality to understand impulsivity. Pers Individ Dif 2001; 30(4): 669-689. doi: 10.1016/S0191-8869(00)00064-7 